最近のエキシマレーザとその応用*

野 末 康 博**

\title{
Present Status of the Excimer Laser and its Applications*
}

by Yasuhiro Nozue**

キーワード：エキシマレーザ，レーザ加工機，リソグラフィ，エッチン グ, CVD, ドーピング, アブレーション,ケラトサージリー

\section{1.はじめに}

いうまでもないことであるがレーザは単なる光源にす ぎないもので，これを搭載し利用する装置となって初め て産業上の便益を提供する事ができる。これを実用化と いうならぱ，レーザの種類は何千と存在するが，それに 比べて実用化されたレーザは数少ない．エキシマレーザ が実用化に至るのか，実用化されずに消え去るのかはい まだ確実てはないが，ここ数年の用途研究とそれに伴う レーザの改良・開発を見ると, 実用化の期待を抱かせる に充分な勢いが感じられることは事実である。

従って，毎年のように様々な学協会誌にエキシマレー ザに関するレビュー1-3)が現れている.本誌はレーザの専 門誌でもなく，半導体プロセスのような特定の有望応用 分野の専門誌でもない。もとより筆者の非才もあり，本 稿では特定の詳細に立入らず，極力広い範囲の動向と話 題を集めて一般的な現状を紹介する事とする。個別の項 目について掘り下げた情報が必要のむきには，本稿末記 載の文献等からの詳細な調查をち願いしたい。

\section{2. エキシマレーザとは}

今日一般的な希ガス八ライドエキシマレーザの最初の 発振は 1975 年であり,最も歴史の浅い新しいレーザの一 つである. 商品化されているものの多くは，三軸直交型 の放電容器をもち, 希ガス ( $\mathrm{Kr}, \mathrm{Xe}, \mathrm{Ar}$ 等) と八ロゲン ガス ( $\mathrm{HCl}, \mathrm{F}_{2}$ 等) 及びバッファガス（He, $\mathrm{Ne}$ 等）を使

*原稿受付 平成元年 12 年 28 日

** 揪小松製作所研究本部 Komatsu Ltd.
㱏 1 典型的なエキシマレーザの発振特性

\begin{tabular}{l|c|c|c|c}
\hline エキシマ & $\mathrm{ArF}$ & $\mathrm{KrF}$ & $\mathrm{XeCl}$ & $\mathrm{XeF}$ \\
\hline 波長 $(\mathrm{nm})$ & 193 & 248 & 308 & 351 \\
パルスエネルギ(mJ) & 200 & 300 & 150 & 100 \\
効率(X) & 1.5 & 2.0 & 1.0 & 0.8 \\
\hline
\end{tabular}

用する.表1に示すようにガスの組合わせにより波長は 異なるが, $0.4 \mu \mathrm{m}$ 以下の紫外域で数十 nsec のパルスで 発振する。一パルス当りのエネルギは数十から数百 $\mathrm{mJ}$, 一秒当りのパルス数は数百パルス程度が一般である.ガ スの寿命はさほど長くなく，数百万パルス毎に交換が必 要である。

発振原理の詳細は多くの一般的解説山もあるのでそち らを参照願うとして，放電等により励起された状態での み存在する二原子分子 (Excited Dimer $=$ Excimer) の解 離によって光を放出する，従来にない高効率, 高出力; 短波長のレーザであり，それだけに広範囲の応用が期待 されているわけである。

\section{3. エキシマレーザ本体の開発動向}

よく知られているように，現在我が国の市場に出回っ ているエキシマレーザは海外メーカからの輸入品が主体 である．国内メ一カの製品は現状では数少ないが，1986 年からスタートした通産省工業技術院の大型プロジェク 卜「超先端加工システ公」放に象徵されるように，官民を あげて研究開発が取組まれており，近い将来には優れた 性能をもつ商用国産エキシマレーザの登場が期待され る。 
エキシマレーザの開発には現状で二つの方向が明確に なりつつある。一つはレーザの用途によらず共通の性能 に関するもので，高出力化，信賴性耐久性の向上，保守 性の改善等である，今一つは特定の用途に必要な性能に 関するもので，様々な開発・改良が試みられている。こ こでは前者の，それも実用機あるいは商用機に採用され たあるいは採用されつつあるような開発項目を中心に解 説する。

\section{1 放 電 技 術}

一般のエキシマレーザは放電によって励起される。こ れが基本性能を決定する最も重要な技術であるので，多 くの研究開発努力が払われている. 基本的にはガス, 電 極等の寿命伸延の見地からグローモードのみの放電が望 ましく、これと高効率の両立がポイントである。研究レ ベルではすでに限界に近いと思われる優れたデータの得 られた例6ももる。

主放電領域を予備電離しておくことが必要なので，こ れも重要なパラメータである。方式としては，

(1) スパークにより発生した極く短波長の紫外光を照 射して予備電離するもの，

(2) コロナ放電により発生された電子の拡散を利用す るもの,

(3) X 線により照射領域を予備電離するもの， がある、現在の製品の多くでは(1)方式が採用されてい るが，より制御された均一な励起を目指して，(2)，(3)の 方式の実用化が研究されており，すでに一部7-9!採用さ れている.

\section{2 パルス回路技術}

数十 $\mathrm{kV}$ のパルス放電によってレーザ発振するため, 効率と耐久性を両立したスイッチング回路が必要であ る.図 1 にいくつかの回路の例を示す，耐久性の見地加 ら最も問題となるのはスイッチング素子で, 通常は水素 封入サイラトロン (放電管) が用いられるが，一般には 図1(a)の最もシンプルな回路を基本として，回路定数を
最適化する事により効率と耐久性を確保する方法 ${ }^{10,11}$ が 採用されている。さらに図1(b)のような, 素子の保護を徹

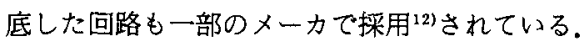

さらに近年研究が進められているのは，放電管を廃止 し，固体素子のみで回路を構成する試み(13)である.高圧に 耐えうる固体素子の開発には团難が伴うことから, 昇圧 やパルス压縮等の技術を併用する事が不可欠であろう。 この技術はさきにふれた大型プロジェクトでも盛んに研 究開発されており，実用化が期待されている。

\section{3 ガス制御技術}

ガス系の制御は大きくニつに分類できる，第一はメイ ンのガス流れに関するものであって，パルス放電する電 極間のガスを素早く入替える事を目的とした技術であ る. 高出力化のために一秒当りのパルス数を増大しょう とすれば，原則的には電極間のガス流速をあげる必要が ある.放電，パルス回路を含む総合的な最適化により， $17 \mathrm{~m} /$ 秒程度の流速で 500 パルス/秒以上の繰返し数が 得られるようになってきている6).さらに高速を目指し た研究も進んでいるが，実用上は当面このへんが標準的 な目標となるであろう。

もうひとつのガス系の制御はガス寿命の伸延のための 技術であって，

(1) 放電チャンバ内部の材筫等の改善,

(2) 発生した有害な不純物の除去,

(3) 運転を継続したままでのガス追加・入替え， など"4)のアプローチがある．地道なガス劣化メカニズム の研究に基づく最近の改善は目覚ましいものがあり，出 力が半隇するまでのがス寿命が $10^{6} \sim 10^{7}$ パルスまで可能 となりつつある。エキシマレーザのカタログ上から「ガ ス寿命」の字が消元る日も遠くないであろう。

\section{4 その他の技術}

最近のようにエキシマレーザの産業用途への展開が確 実視されるに従い, 従来の研究用レーザから脱皮する必 要が高まり,ことに耐久性・保守性の観点から様々な改

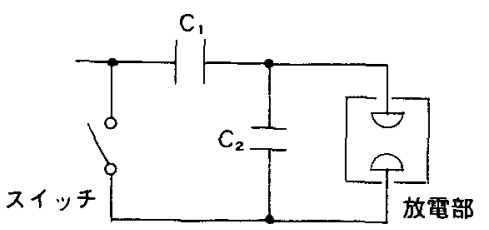

(a)

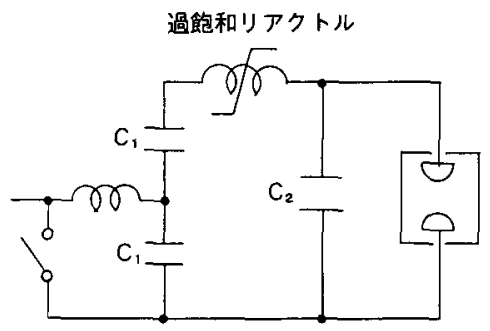

(b)

图 1 典型的なパルス回路の例 
良が施されている。

例えば電極材料の工夫改善やウインドのくもり防止等 が試みられている，同時に，消耗がまねがれない部品の 交換が容易なユニット構造の採用もいまや常識となりつ つある.こうした様々な技術改良・開発がシステマティッ クに実施され，採用されて製品となるわけであるが，上 記の産業用途への採用に当って，もうひとつの問題が生 じている.それはレーザ性能の評価基準の問題である. 例えば紫外レーザ光の強度測定標準（現在の市販パワー メータではメータ毎に測定値が異なる）から始まって， 寿命の力タログ表示基準等の標準化が望まれる.JISで も安全基準 ${ }^{15)}$ が最近公布されたばかりであるが，さらに この方面の充実が期待される。

\section{4. 応用技術の開発動向}

学術的に考えれば，エキシマレーザの応用はそれなり の分類ができるのであろうが，ここでは実務的な立場か ら産業の分野別に分類して，それそれれの応用技術開発動 向を概説する，あわせて，特定の応用にむけて開発され ているレーザおよびレーザ応用製品についても言及した is.

\section{1 半道体製造プロセス}

現在最もホットに技術開発が進められている分野であ る. 従って，最近現れたレビュー1,21でもさらに詳細に各 分野の専門技術者が解説を行っている.

\section{1 .1 露 光}

LSI の高密度化，回路微細化のキー技術の一つは露光 プロセスであり，水銀灯を光源としたステッパ装置がひ ろく使用されている，近年，微細化がさらに進行するに ともない，分解能を向上するため，光源はより短波長に なりつつある.なぜなら，縮小投影光学系の分解能は波 長に比例するとともに，焦点媣度の点でも有利になるか らである ${ }^{16)}$. 従来は水銀ランプの $\mathrm{g}$ 線 $(436 \mathrm{~nm})$ と $\mathrm{i}$ 線 $(365 \mathrm{~nm})$ が使用されてきたが， $\operatorname{KrF}(248 \mathrm{~nm}), \operatorname{ArF}(193$ $\mathrm{nm})$ エキシマレーザを光源としようとしている，装固の 構成を図 2 に示す。

光学系の構成方式として，通常のレーザを用いてレン ズ系を色消しとするものと，発振スペクトルを狭くして 色消ししないレンズを用いるものがある，短波長域では 使用できる硝材が少ないため後者が有望と見られ，これ に適合したレーザの開発かが盛んである。

\subsection{2 エッチング}

反応性イオンエッチングが現在の主流であるが，低損 傷の方式が求められており，図 3 のようにエッチングガ ス霜囲気中でエキシマ光を照射するレーザ法が研究され
ている，ArFレーザにより， Si, Al 等について可能性を 示唆する良好なデータが得られている17)。この方法では 単に低損傷というだけでなく，フォトマスクを用いるこ とによりパターン転写エッチングも可能で，実用化され ればプロセスへのインパクトは大きい.

\subsubsection{CVD}

原料ガスを熱エネルギ，放電又は光によって分解し， 基板表面に堆積させて薄膜を形成しようとするプロセス で, 装置の構成は図 3 とほほ同様である.ここでも低温・ 低損傷(または高堆積速度)，パターン転写をめざして研 究が進められている.エキシマレーザは ArFが多く使用 され，基板としては Al, Si のみならず，GaAsなどの化 合物半導体に応用した例が多く報告されている ${ }^{18)}$.

\subsection{4 ドーピング他}

半導体の製造では，母材結晶中に少量の不純物を注入 することが必要である。均一で深さの制御されたより良 いドーピングを行うために，従来の加熱㹡散法，イオン 注入法にかわるレーザ法が試みられている ${ }^{199}$. 基板とし ては Si, GaAsなどが，レーザとしては XeCl から ArF まで用途により椂々の条件で寒験されているが，一部で は XeCl レーザをべースとした加工装置として市販され 始めた例20ももる。 ドーピングとは逆に不純物を取除く

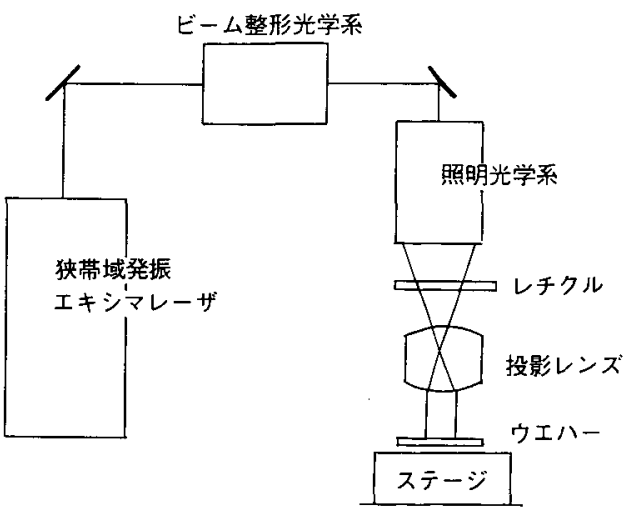

图 2 エキシマレーザ露光装置

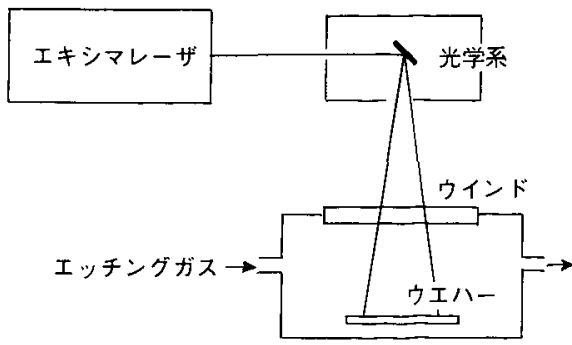

図 3 レーザエッチング装置 
ゲッタリング装置 ${ }^{21)}$ 実用化されており, 今後の動向が 注目される。

これらの他, ドーピング後の内部構造を安定化するた めのアニーリング等も含めて, エキシマレーザのみでな く, Arレーザや各種ランプによる光プロセスが幅広く研 究22)されていることを付言しておく.

\section{2 半道体以外の微細加工}

半導体プロセスの項からも理解されるように, エキシ マレーザによる加工は, 本質的に熱を利用していない. この点が炭酸ガスレーザやYAGレーザと異なる，ポリ マのアブレーション ${ }^{23)}$ その典型的な一例で, 溶融や酸 化を伴わず，分子の結合を紫外特有の高いフォトンエネ ルギによって直接分解して, 穴明けなどの加工が可能で ある.図 4 に例11)を示すように, 加工箇所周辺の熱影響部 がほとんどなく，極めてシャープな形状が得られると同 時に，短波長ならではの高分解能が特長である.

マーキングでは YAG レーザや TEA レーザでは困難 であった高品位の加工が可能で; セラミッタ, ガラス等 の材料にも適用されている。ことに最近増加している微 小な SMD パーツ等には最適であろう。

この応用分野でも加工機として一部で市販が始まって おり, 生産技術の研究用もかねた汎用のもの ${ }^{11}$, マーーカ専 用機 24 等がある。

\section{3 化学工業プロセス}

これまでに紹介した応用例は広い意味ではすべて化学 反応に関わるものであるが, 物質の合成, 分離などのい わゆる化学工業プロセスにもエキシマレーザの利用が研 究されている25).

この分野でもすでに光プロセスとして水銀灯を利用し た研究が行われているが，商業生産で実用化されたもの はほとんどないようである。単純に比較すれば，エキシ マレーザのコストは水銀灯よりはるかに高いわけで，指 向性とか尖頭パルスエネルギの強さなどの特徴を生かす と同時に, 付加価値の高い生産品を対象とする必要があ

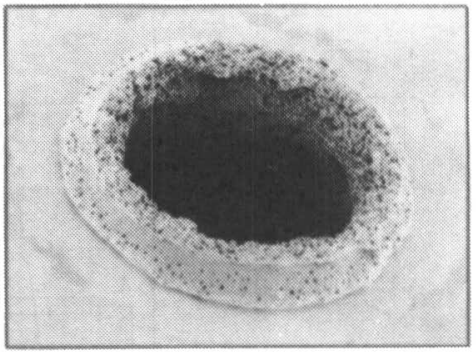

(a) 炭酸ガスレーザ
る、その意味でヴィタミンやフェロモンの合成などが有 望とされるが，実用化にはまだ問題点が山積しているよ うである.

ウランの同位体分離は実用化の可能性も高く, 精力的 に研究開発が行われているが，レーザ法そのものに対し て遠心分離法などの競合がある。さらにレーザ法の内て も原子法は赤外のラマンレーザを利用する，分子法なら 色素レーザ励起光源として，銅蒸気レーザかエキシマ レーザが使われる事になるという，商業化にはまだまた゚ 曲折が予想される状況である ${ }^{26)}$.

\section{4 医療機器}

医療の分野では炭酸ガスレーザメスやArレーザのコ アギュレータ（網膜剝離の固定手術装置）など，レーザ の利用が展開されているが，ここにきて急速に注目を集 めだしたのがエキシマレーザである。骨切断には熱によ る炭化のないエキシマレーザが有効27)といわれ，血管の 狭窄, 閉塞物の除去にも有望 28 ) さされる。いずれも $\mathrm{KrF}$ は発振波長の近傍に DNA の吸収があり，遺伝情報破壊 の危険があるので $\mathrm{XeCl}$ または $\mathrm{ArF}$ が使用されている ようである。

しかしなんといっても最近のハイライトはケラトサー ジリーである.これはポリマ加工と同様，紫外光による アブレーションを角膜表面に発生させ, 近視・遠視を永 久的に治療しようというものである。すでに FDA の認 可をえた米国の数社が専用の機器を試作し, 手術の試行 を開始しており，良好な成果を得ているとのことであ る ${ }^{29)}$. 国内での実用化についてはまだまだ時間が必要と もいわれるが，エキシマレーザの特徴を巧みに生かした 応用であり，今後が期待される。

\section{5 光 $の$ 他}

従来から行われている, 分光分析用光源としての利用 は，着実に一定の市場を形成しているようである。最近 の話題では大気観測を目的としたレーザレーダへの応 用 ${ }^{30)}$ がある。また色素レーザの励起には波長帯域を広く

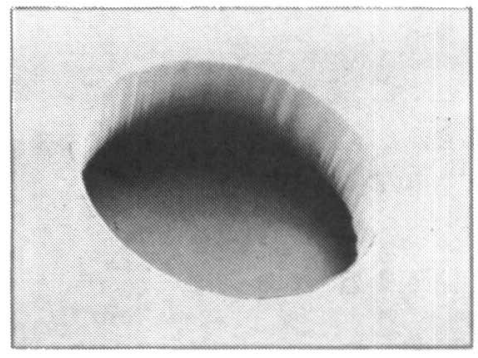

(b ）エキシマレーザ

図 4 ポリイミドのレーザ穴（直径 $0.3 \mathrm{~mm}$ ）加工例 ${ }^{11}$ 
とれる紫外レーザが有利であり，今後とも活用されてい くであるう.こうした分野でまず利用可能と思われる， 安価でコンパクトな全く新しいタイプのエキシマレー ザ31,32)が出現しており，動向が注目される。

\section{5.おわりに}

最後に周辺技術の動向の一端を紹介して, しめくくり としたい，始めにも述べたように，レーザを単なる光源 にとどめず，装置として実用化するには加工機としてシ ステム化する必要があり, それには周辺の技術の進展が 不可久である．たとえば光学素子の技術やセンサの技術 がこれに当たる．この方面でも，光学薄膜の損鹪の系統 的な研究33)や紫外線センサの開発 ${ }^{34)}$ が成果をあげてお り，たのもしいかぎりである。

今後とも，こうした着実な研究開発の努力が樻重ねら れ,さらにはシステム化のノウハウが蓄積されて，メー カ・エーザ一体となった協同作業により, エキシマレー ザの産業用市場が確立される事を切望するものである. 執筆にあたり資料提供戴いた各位に謝意を表する。

\section{参考文 献}

1) 前田他：レーザー研究, Vol. 16, No.4 (1983), $148-229$

2) 豊田他 : 電気学会雑誌, Vol. 108, No. 11 (1983), 1077-1099

3) 渡部：固体物理, Vol. 23, No. 11 (1988), 861-867

4) 植田：精密工学会誌, Vol. 55, No. 5 (1989), 837840

5) 清水, 牧田, 佐藤：応用物理, Vol. 57, No. 4 (1988), $522-527$

6) 堀田：レーザー研究, Vol. 16, No. 4 (1983), 191199

7) 江浦, 若田, 中谷, 永井, 坪井: 三菱電気技報, Vol. 63, No. 4 (1989), 273-276

8) XMR エキシマレーザ応用装置 (製品カタログ), 㧣 MBK マイクロテック

9) EMG401 2J Excimer Laser (製品カタログ), Lambda Physik GmbH（丸文陎扱い)

10) Variable Beta High Efficiency Excimer Lasers (技術説明資料)，Questek Inc.(侏理経扱い)
11) Index 200 Industrial Excimer Lasers (製品力タ ログ). Lumonics Inc.（ルモニクス・パシフィッ ク侏扱い)

12) Excimer Lasers with Magnetic Switch Control (製品カタログ), Lambda Physik GmbH（丸文 (侏扱いつ)

13) T. Shimada, M. Obara and A. Noguchi: Rev. Sci. Instum., Vol. 56 (1985), 2018

14) Questek Series 2000 excimer lasers (製品力夕 ログ), Questek Inc. (侏理経扱い)

15）「レーザ製品の放射安全基準」, JIS C 6802-1988 日本規格協会

16)塩竹：電気化学および工業物理化学, Vol. 57, No. 4 (1989), $272-276$

17) 広瀬：電気学会雑誌, Vol. 108, No. 11 (1983), 1081-1085

18）青柳：レーザー研究, Vol. 16, No. 4 (1983), 486497

19) 後藤：電気学会雑誌, Vol. 108, No. 11 (1983), 1090-1094

20) 入江, 前田, 村岸: 電子材料, 1986 年 12 月号, 8488

21）梶川，木原，鈴木，中村：NEC技報，Vol. 41, No. 15 (1988), 115-119

22) 広瀬：応用物理, Vol. 57, No. 12 (1988), 18951900

23) S. Lazare and V. Granier: Laser Chem., Vol. 10 (1989), 25-40

24) Lambda Mark, An Excimer Laser non-contact Marker (製品カタログ)，Lambda Physik $\mathrm{GmbH}$ (丸文㧣扱い)

25) 矢部：ペトロテック, Vol. 11, No. 12 (1988), $1141-1146$

26) 東:エネルギーレビュー, 1985 年 4 月号, 10-16

27) 佐藤, 山本 : O plus E, No. 109 (1988), 94-100

28) 荒井, 菊池: O plus E, No. 109 (1988), 75-81

29) 小沢：光技術コンタクト, Vol. 27, No. 4 (1989), $203-211$

30) 杉本：センサ技術, Vol. 9, No. 2 (1989), 22-26

31） GX-100 紫外導波路型エキシマレーザ(製品カ夕 ログ), Potomac Photonics Inc. (丸文侏扱い)

32) SEL 500 Switchless excimer laser (製品カタロ グ), Sopra（オーテックス侏扱い）

33）伊藤, 黒田, 小倉：東京大学生産技術研究所報告, Vol. 35, No. 1 (1988)

34) 池戸 : センサ技術, Vol. 9, No.6 (1989), 235-237 